\title{
Intellectual Property Management in Technology Transfer
}

\section{among Companies}

\author{
ZHANG Yang \\ (School of Management, Huazhong University of Science and Technology, Wuhan 430074, China)
}

\begin{abstract}
Intellectual property management plays a very important role in the process of technology transformation among different companies. This article discusses the main methods and mode which companies usually used to manage their IPM in market. Some suggestions are also provided for the company managers.
\end{abstract}

Key words: intellectual property management; technology transfer; market

One of the effects of globalization is the relocation of production from the technology rich companies to low labour cost companies. This is a threat for suppliers and manufacturers in technology-rich countries, whose customers turn their heads to low labour cost countries. And this trend creates opportunities for contract manufacturers and service industries.

From a historical and international perspective, we are witnessing a dramatic shift in the importance of the five main drivers for value adding: technology, production, marketing, logistics and support. From a historical and international perspective technology, in the form of know how and trade secrets, has emerged as a key factor in this process.

In technology rich countries, there is a vast pool of know how waiting is to be untapped. In emerging markets, there is an enormous demand for know how waiting is to be filled. This "trade in technology" could be one of the answers to a changing world. But we need to improve the matching process for this trade, i.e. through licensing. When it comes to transfer of know how and trade secrets which are hardly "patentable", as is the case of most industrial know how, both parties, licensor and licensee alike, still seem to be reluctant to cross bridges. There is a role for institutions and governments to facilitate this matching process by improving the "climate" of intellectual property rights, particularly in know how and trade secrets.

From a historical perspective, the importance of technology has been increased dramatically. Since the economic recovery, we have four main distinguished trends: price, quality, speed and new, unique products. This triggered the trend for quality products. All kind of quality assurance systems, many of them from Japanese originally, left their mark on the way that companies were managed. It culminated into the widespread acceptance of the quality assurance system, both in multinationals and companies alike.

The main drivers for change in intellectual property importance can be described as follows:

(1) Technology. The dramatic increase of importance due to the market demands we described above was not the only reason. The relocation of production to low labour cost countries has confronted technology rich industries with an additional problem: protection of know how. It is widely accepted that direct foreign

ZHANG Yang, senior engineer, Ph.D. candidate of School of Management, Huazhong University of Science and Technology; research field: intellectual property management of state-owned corporation. 
investments from industrial countries to developing countries have created a diffusion of technology into the recipient economies. Technology rich industries are mindful of the fact that without effective intellectual property system in the recipient countries the transferred technology may be used to compete against them thus denying the opportunity for adequate returns to their investment/technology. Unfortunately, most potential technology recipient countries do not have strong intellectual property systems and as a result technology rich industries prefer to keep their R\&D departments "close to the chest" and not move along with their production units. This prevents the flow of technology through licensing.

(2) Production. At the dawn of industrialization, basic industries required huge investments in land, buildings, machines and labour. It is therefore logical that producers and manufacturers would receive the bulk of the total value added in the supply chain. But the increasing prosperity had its effect on labour costs, which constituted in most sectors between $50 \%-70 \%$ of the cost of production. Combined with the open border/trade liberalization policies of most developing countries, this resulted in a wave of relocation of production activities towards low labour cost countries. This is most of all noticeable in the garments and in the electronics industry. Production as a value adding activity has deflated to a low level and will continue to flow to the lowest point.

(3) Marketing. "You can buy a T-Ford in any color you want, as long as it is black". Henry Ford's famous quote illustrates the role of marketing in the 1920s. It was a seller's market and people would buy whatever industries would produce, such was the demand for new products. After some decades, producers started to understand the need for marketing as a value adding activity. Companies realized the importance of trademarks and industrial designs in marketing strategy. General motors would position similar cars (Buick, Chevrolet, Pontiac or Oldsmobile) for different market segments and command a different price for each of these brands. It is difficult to explain exactly why we are prepared to pay a premium for Nike, sneakers over other less "marketed" sport shoes. Is it because of superior quality (production), design (technology) or the name/logo (marketing)? Is that same marketing the reason why we pay more for a PC with "Intel inside"? The fact is that the "marketing factor" plays a dominant role in the purchasing process, even more than before. Seller's markets have turned into buyer's markets, competition is global and the battle for markets is influenced more than ever by advertising budgets.

Obviously, now all industries are searching for new added value in the technology and marketing "boxes". The big money seems to be there. For manufacturers in developing countries, the choices are less obvious. Huge profits upwards in the supply chain, close to consumers and end-users are luring. But adding value through marketing means substantial investments in time and money. Investments in market research, market information, distribution channels, advertising, publicity and/or brand building. Another obstacle, certainly in B2B, is the customer himself. He is close to the end user markets or consumers and certainly does not want his supplier, the contract manufacturer, to compete with him on that same market.

From these perspectives it seems that both parties, industries with technology and contract manufacturers alike, should opt for the technology route. For contract manufacturers it is the surest way to increase their added value and stay away from the downward spiral that affects all production activities. For technology rich industries, it could be a solution to the ever increasing problems around outsourcing and off-shoring. Cost advantage is the main driver for outsourcing, but both parties are having second thoughts about the benefits of outsourcing, particularly in manufacturing. Lack of understanding of the technological needs to manufacture a product in a correct and most effective way is the main culprit. Furthermore, limited use of intellectual property in facilitating technology transfer and in marketing strategy can be said to contribute to the reluctance of the two sides in 
“crossing bridges".

Transfer of know how and trade secrets is not restricted to "technical" know how. Know how in each of the value adding activities is "fit for transfer". Production and logistical know how are the first choices when it comes to contract manufacturing.

Companies that want to increase their share in emerging markets may opt to transfer their marketing secrets and support know how to local companies in those markets in return for a royalty on sales volumes.

Unfortunately, the licensing instrument is underutilized by SMEs. This is because licensors are afraid of uncertainties about the protection of their intellectual property, including trade secrets. On the other hand, licensees are reluctant to accept the often severe restrictions that come with license agreements. These in turn are the result of licensors being overcautious to protect their interests. The vicious circle is completed.

Transfer of technology can be a remedy against the problems that proliferation of production and trade has brought along. But then again, a lot of work need to be done to make the licensing of know how and trade secrets more accessible for those who need it most.

References (omitted)

(Edited by Jimmy Wang, Gavin Dai and Shirley Hu)

\section{(continued from Page 64)}

evaluation index. Then organize nine personnel inside and outside the company and they are three different kinds: management, technology and economic personnel. They do the form-like satisfaction evaluation. Evaluate the initial evaluation result synthetically based on the expert evaluation table and the principle that different evaluation main body difference treatment.

The result of synthetic evaluation shows that the technical and economic benefits, the situation of digest and absorbing, and the foreground of project A are better; project B still has obvious disparity compare with A. This supplies reference of choosing digest and absorbing project and further technical economic decision-making for the company and its higher power administration.

\section{References:}

[1] Nonaka I., Takeuchi H.. The Knowledge Creating Company. Oxford: Oxford University Press, 1995. 2005(3).

[2] Nonana Ikjurio. The Concept of "Ba": Building a Foundation for Knowledge Creation. California Management Review,

[3] Gunther Tichy. The Over-optimism among Experts in Assessment and Foresight. Technological Forecasting and Social Change, 2004(5) .

(Edited by Jimmy Wang, Gavin Dai and Shirley Hu) 